\title{
Teaching Indonesian Language Courses with Insight Into Wetlands in the 4.0 Era
}

\author{
Ahsani Taqwiem \\ Department of Indonesian Language and Literature Education \\ Universitas Lambung Mangkurat \\ Banjarmasin, Indonesia \\ ahsanitaqwiem@ulm.ac.id
}

\begin{abstract}
Bahasa course is one of the compulsory courses in the curriculum component of the college. Mandatory means all levels and all scientific fields should present this course as a basic course. Entering the 4.0 era, challenges to this subject are more substantial. Besides completing the subject, this course is also advisable to be a personality course that can help the success of the student. Growing in the wetland environment, it must base the materials selected on locality. The opportunity to integrate concepts and themes following the wetland environment with the linguistic material will be the language in this writing. Materials that can be simulated character education will also be comprehensively outlined in this writing. This article will be a reference to find the right type of learning resource to be applied as a language course in a wetland environment in the era of the industrial revolution. In addition, this article tries to explain the important stages if blended learning is to succeed.
\end{abstract}

Keywords: teaching, Bahasa, blended

\section{INTRODUCTION}

Entering the era of the industrial revolution was born a new challenge that brought disruption in all fields. This disruption also hits the very elementary world of Education. The pattern of learning relationships has changed a lot compared to a few years ago. The limitations of space seemed to disappear when technological advances came as a solution. This era is also a challenge for Indonesian language courses at the tertiary level.

Indonesian language courses are general basic courses mandatory for all students. This subject is included in personality development, so the Indonesian language bears a more substantial burden compared to other subjects. The compulsory nature of it makes it necessary for this subject to respond to the changes of the times. Therefore, it can keep up with the rhythm of the present.

The industrial revolution is an era that is continued from the previous era. The invention of the steam engine is a marker of the beginning of era 1.0, which slowly found a replacement from limited sources of energy to power from the engine. The invention of the steam engine made work more effective.

The 2.0 industrial revolution took place in the $1900 \mathrm{~s}$. This era is often marked by the invention of electricity. The emergence of electricity turned out to be a trigger for many other technologies such as cars and telephones to emerge.
Another change in this era is the discovery of the concept of a production line that can increase productivity.

The 3.0 industrial revolution is characterized by automation. The automatic system was created because of a revolutionary invention called computers. The presence of computers that are followed by the internet not only changes the production process but also changes the pattern of human life to enter the all-digital world.

Era 4.0 is marked by the discovery of supercomputers and artificial intelligence. This discovery makes the productive system makes full automation without the intervention of human labor. This era is for some experts only development for the previous era. However, reality presents evidence that this era provides significant development in all aspects of life.

This significant change in lifestyle in the 4.0 era became a challenge for the world of Education. Developed countries that have infrastructure readiness have entered a significant change in life. Besides, these countries have long prepared and socially to live in the digital age.

Indonesia, as a developing country, must keep pace with developments quickly. The speed of adapting Indonesia differs from developed countries that are fully prepared. Adaptation to changing times also affects the world of Education. Classical teaching patterns have faded and are less relevant to be used to face the digital age.

Students are also in a new condition compared to previous generations. The presence of a device with an internet connection becomes a natural sight. Even though students are conditions of learners who are mature enough and responsible, this matter, if not considered, will also hamper the learning process if the technology is not expected and put to good use. Lecturers must understand that the generation they face is native digital generation if the lecturer considers technology as a distraction and tries to separate it from learning. Maybe the achievement of learning objectives is not optimal.

As digital immigrants, lecturers must prepare for change. Lecturers should not close themselves and stop learning simple learning technologies that are practical and applicable if the previous era relied on a whiteboard. Now, LCD projectors have become commonplace to use. In the past, teachers and students had to meet now that it could be replaced with interactive learning to use video conferencing. 
Things like this should not be a scourge that is disturbing learning but must much as to feel the benefits.

The fact shows that internet connection has become a kind of primary need for most Indonesian people. A sense of optimism that blended learning can be a solution combining classical and contemporary learning can be felt when we look at data about internet users in Indonesia. Statistics on 2019 data shows that in 2018 there were 95.2 million users, growing by $13.3 \%$ from 2017 with 84 million users. In the years ahead, it is estimated that internet users in Indonesia will increase with an average growth of $10.2 \%$ in 2018-2023 [1]. An extraordinary number that proves internet technology has become an essential part of everyday Indonesian society.

We expect blended learning as a solution for so many aspects of learning. Variations in learning resources that are increasingly unlimited make each other must be harmonized so as not to overlap. Teachers must understand the definitions and aspects of the application when using blended learning. This paper seeks to elaborate on blended learning to teach Indonesian with an insight into the locality of wetlands.

\section{LITERATURE REVIEW}

Talking about the concept, it must prepare us with various opinions regarding the definition of blended learning. The diversity created is influenced by many aspects that make it impossible to believe an absolute definition is perfect for providing an explanation of blended learning. That diversity becomes an advantage that makes it easy for the audience to determine the best definition following their needs in understanding the concept of blended learning.

Blended learning is derived from America. It feels natural because as a developed country with rapid technological progress, integrating technology in the aspect of Education is inevitable. There are many books and references that can enrich knowledge about blended learning. This diversity is coupled with the blurring of blended learning equivalents in other languages, so it might be in a region of blended learning to have a different naming but still in the same concept, for example, the term hybrid learning which is more prevalent in America to explain pedagogical approaches that combine face-to-face meetings with instruction who uses a computer.

Blended learning is the concept that includes framing teaching-learning process that incorporates both faces to face teaching and teaching supported by ICT. Blended learning incorporates direct instruction, indirect instruction, collaborative teaching, individualized computer-assisted learning [2].

Blended learning is the most logical and natural evolution of our learning agenda. It suggests an elegant solution to the challenges of tailoring learning and development to the needs of individuals. It represents an opportunity to integrate the innovative and technological advances offered by online learning with the interaction and participation offered in the best of traditional learning. It can be supported and enhanced by using the wisdom and one-to-one contact of personal coaches [3].

Another explanation tries to divide it into three definitions: (1) the integrated combination of traditional learning with web-based online approaches, (2) the combination of media and tools used in an e-learning environment, and (3) the combination of several pedagogic approaches, irrespective of learning technology use [4].

The first understanding refers to an understanding that is developing - the second understanding views blended as a model that emphasizes the incorporation of several types of learning. While the third understanding is more technical and specific that tries to explain substantial things about the richness of this approach with various dimensions in it. These three definitions are very contrasting with each other but also offer a choice of definitions that touch on a simple to complex aspects.

Speaking Indonesian, according to SD Dirjen Dikti on Personality Developers Course No. 43 / Dikti / Kep / 2006, it must be understood that Indonesian courses have an additional burden, namely as a subject that can develop competence and personality [5]. Demands which need hard work to make it happen. We expect blended presence to provide convenience for Indonesian language courses to fulfil these desires.

Not just finished, the Indonesian language course was also demanded to prioritize local wisdom to sustain regional cultural preservation which became the pillars of national culture. Taught in southern Kalimantan as swamp and river areas, the Indonesian language taught must be integrated with wetland conditions. It relates the linguistic concepts that are given as much as possible to the concept of wetland ecology, which refers to the ratification of the 1991 Ramsar Convention. Wetlands are areas of marsh, fen, peatland or water, whether natural or artificial, permanent or temporary, with water that is static or flowing, fresh brackish or salt, including areas of marine water, the depth of which at low tide does not exceed six meters [6].

\section{RESULTS AND DISCUSSION}

E-learning is fast becoming an essential component in learning in the world of higher education. The effectiveness that uses technological advances so that fading distance and time is an inevitable necessity. The digital age seems to be a natural phase and a challenge for some teachers who start teaching in the era before digital. Some reasons e-learning is tricky, include:

First, students who demand the use of technology and will put pressure on teachers to improve their abilities. If this cannot be achieved, there is a feeling of not being maximal in teaching the instructor feels that.

Second, the pressure imposed because of the demands of using technology adds to the burden of teachers who from the beginning of learning also must plan learning that combines online and offline effectively. If this is not achieved, it will undoubtedly produce feelings of dissatisfaction from students. Learning becomes not optimal and not fun.

Third, blended learning by using ICT demands sustainability. The materials used must be quickly produced, stored, retrieved, and reused. This kind of material has more difficulties than disposable material. Teachers must try harder to design this kind of building material.

Fourth, teachers at one point will feel uncertainty in trying to go with the flow so quickly. Investment of time and energy will continue to be questioned whether all the 
project work? (7) How does the use of different media and communication forms together in the learning milieu? [9]

the results compared to the effort that has been passed [7].

Learning that is planned to use blended by utilizing ICT will have a more substantial burden when the courses taught are unique, which requires more effort to realize ideal learning in the classroom. Language courses, for example, have four skills that are always asked whatever the material is given. Does the learning provide cover four aspects such as listening, speaking, reading and writing?

Use of modern technologies, such as computers, Internet-resources, special educational multimedia programs, as well as modern technical equipment, allows optimizing the teaching process. The advantages of using innovative technologies are following: (1) increase of motivation and enthusiasm of students and teachers through active involvement in the process of live communication, possibilities of language acquisition are increasing thanks to the cooperation, interaction and communication in learning language, (2) great potential for a variety of teaching methods and teaching to the needs of each student, (3) job satisfaction, where the result is visible after each section, (4) self-education of student's personality through the skills to locate, retrieve, evaluate and analyze relevant information, (5) intensification of the educational process that allows to rationally organize the educational process, both in the classroom and in the condition of independent work of students, (6) professional development - communication skills of students and teachers [8].

\section{A. Lesson Plan}

Avoiding the results less than the maximum, it must be understood that the crucial stage must be prepared carefully by the teacher is the planning stage. Teachers must understand that blended learning is an approach that can be adapted to the conditions and learning needs. If the teacher splashed into the blended jungle without a plan, the teacher's potential will be lost and confused in the middle of the road to determine the direction of learning is likely to occur. It is at this stage that the essence of traditional learning that is deeply rooted in learning plans is worth observing. Do not let learning be carried out with principles essential to use technology or that are important online, but its meaning cannot be determined. Learning objectives must be clear.

Besides, although not, the portion between face-to-face and learning must be considered. Several educational institutions already have regulations as a legal umbrella that regulates this division. Also, a clear plan provides convenience for conducting tests and evaluations of learning. The carefully planned test format and evaluation format will ease the teacher's burdens.

Some crucial questions that must be answered before implementing the blended learning approach, for example: (1) Do the media give the students a possibility to observe the teacher's communication? (2) Do the media give the teacher a possibility to observe the student's communication? (3) Do the media give the students a possibility to observe the other students' expressed understanding of the study? (4) Do the media give the students a possibility to observe their own expressed understanding of the study? (5) Do the media offer the possibility of differentiating in the choice of information and in the choice of ways to communicate? (6) Do the media give the teacher the possibility of organizing the communication between teachers/students? In groups and

\section{B. The Art of Blending}

After passing through the initial problems, face a consequence because they chose blended learning, which is blending. It is possible for a blended teacher to do what he wants and conditions when learning takes place. However, as a scientific process aimed at achieving a particular goal, blended learning should have a mature and exciting blend material.

The blended process that takes place is influenced by teacher competence. The more inspirational and creative a teacher is, we can expect the more reliable and attractive. This creative touch has an aspect of art in it. Selecting a variety of media and materials to free students in building ideas is valuable art.

Blended learning challenges teachers with openness to too many aspects to be integrated into learning. On the one hand, this openness provides an excellent opportunity for creative instructors to create an ideal learning atmosphere without complaining about distance and time. However, this is a formidable challenge for teachers who are mentally unprepared to accept changes and the latest technology on a massive and continuous basis. Problems will increase if the institution does not take part in encouraging the use of technology by preparing infrastructure in a conducive manner. Moreover there are no rules or legal basis that governs it. The challenge to realize blended learning will be a problem.

The teacher is tested with technological changes that also change the way we interact with each other socially. The presence of social media that is very close to the lives of students can be an obstacle if it cannot be transformed into an advantage for learning. Rapid change will make some people unable to follow it will collapse and give up. This is where the need to wisely determine the aspects that will be utilized to carry out blended learning.

Interest in where these new ideas are taking this area and an application of what has brought us here has both shaped this book. Developments in blended e-learning are not isolated from the changing needs of institutions and changing practice in education. Staff trying to implement blended elearning need practical advice that will help them rapidly develop and implement ideas. This book offers advice, but also acknowledges and examines the impact of the broader environment and the wider expectations of students and teachers in further and higher education today [10]

\section{Material Integration}

Era 4.0 is characterized by the potential to connect massively and massively easily to one another. This connection gives the advantage that we need not carry one thing physically one at a time according to its function if we want to use different functions. In simple terms, we only need a smartphone to give students an opportunity to watch video learning materials and work on the questions on the site that has been provided, for example. Such facilities require abilities that cannot be said to be difficult but still need to be learned. 
For example, when spelling material that talks about sentences. Then the teacher can directly give concrete examples such as providing links to online news portal sites to students in which there are various forms of sentences. This is where the interaction between students with concrete learning material occurs. The selection of material before it is given to students requires the wise attitude of the instructor so as not to deviate from the learning objectives. The connection with the concept of wetlands can be started by discovering social and cultural discourses related to the wetland environment.

If in the classroom physically, we have a specific building size and location, then in online learning, we need is an online class or better known as the learning management system (LMS). Through this LMS, the instructor organizes all activities related to learning, enjoy organizing a class. LMS is now very developed from paid to free to use. Because it is very diverse types each other has advantages and disadvantages. This is where the learning design is needed so it can be a reference when choosing an LMS that suits your goals and needs. Paid LMS is always better not to be properly immersed; it all depends on the user. although paid LMS certainly provides certain conveniences and features. Using LMS will return to how the level of creativity of a teacher in managing classes online.

One key to success in managing online classes is the availability of material digitally. All solid material must be processed into digital files so they can be shared and used maximally through online classes. The material in the form of text, For example, in the history and development of Indonesian, must be changed to pdf. It can compress pdf type files to a size that is light enough so that when uploaded and downloaded it is not too big. The problem of file size is often also an obstacle because not all internet connections owned by students are fast enough to access large files. It feels like pdf is the best conversion choice for a material in the form of text.

Paragraph material or scientific papers can be enriched and provided using video. The problem with the material in the form of video is needed if it is not found on popular sites like YouTube, the solution is to make it yourself. Making videos can challenge for some people. The readiness of the tools and materials must be proper enough so that the video produced is also worth watching. Need to learn to make the ideal video. However, if it is finished with a good video, then the video will continue to part of the learning resource if the topic being discussed is still relevant.

If the video is severe enough, sound recording can be an effective solution. Each mobile phone is equipped with a voice recorder that is good enough if used ideally. The material in the form of sound recordings will rely on the sound and content of the material without being able to expect visual help. The limitations of the tool should not hamper creativity. Voice recordings in $\mathrm{mp} 3$ format, for example, or more modern ones using podcasts that allow students to listen to sounds using the internet network are effortless and helpful.

Media such as pictures can also increase the wealth of learning resources in teaching Indonesian. Images are also straightforward to find using an internet network. When explaining spelling that requires examples of sentences with a variety of variations, it is possible to use attractive images that are associated with the concept of wetlands such as pictures of floating markets, images of sales, swamps, and rivers.

The various media above will be useful if given in an integrated container cellphone or laptop can access that. This is where the role of LMS can be a forum for teachers to manage various learning resources. Through LMS, it is also possible to discuss and provide tests to students.

At a higher stage, some LMS and self-service provide video conferencing as a duplication of the face-to-face meeting process. Video conferencing is very good because there is a visual meeting between the instructor and participants. However, behind all the goodness of this teaching using video conferencing requires a device with a reasonably high specification and a stable internet network. This is still an obstacle because Indonesia is still in the developing stage towards a country with an ideal internet infrastructure.

Back to the concept of blended, all learning resources that have been presented above in teaching Indonesian must be regulated to be maximized. Using technology also does not replace face-to-face meetings. Good collaboration between instructors and participants in using a variety of learning resources will increase the potential for achieving learning objectives more effectively and efficiently.

\section{CONCLUSION}

The era of the industrial revolution gave birth to new challenges for the world of education. The challenge is in the form of questions about how a teacher can adapt and respond positively to technological progress. This also hit Indonesian language lecturers. In order to make it through this era of distractions, adaptive mental attitude and continued learning must be possessed. The solution offered is to use blended learning. Avoiding failure or imbalance in using blended, a teacher must design a learning plan properly. Also, in conducting bled, it requires sufficient wisdom and knowledge to produce an ideal portion of the various learning resources used. Competence using technological platforms will determine the success or failure of blended learning. When learning resources are well prepared, in the industrial revolution era, these materials will be maximized if they can be integrated. The integration will maximize the use of text, images, sound and video in learning with the blended learning approach.

\section{REFERENCES}

[1] Statista. Number of internet users in Indonesia from 2017 to 2023. Retrieved from https://www.statista.com/statistics/254456/number-ofinternet-users-in-indonesia, 2019.

[2] K. L Dangwal, "Blended learning: An innovative approach" Universal Journal of Educational Research, vol. 5, pp. 129-136, 2017

[3] K. Thorne, Blended Learning: How to Integrate. Great Britain: Kogan Page, 2003.

[4] D. Whitelock, and A. Jelfs, "Editorial: Journal of Educational Media Special Issue on Blended Learning", Journal of Educational Media, vol. 28, pp. 99-100, 2003.

[5] A. Taqwiem, Mata Kuliah Bahasa Indonesia Sebagai Upaya Menumbuhkan Generasi Bangsa Yang Berkarakter. Seminar Internasional "Membangun Pendidikan Berbasis Nilai-Nilai Kebangsaan,” 99. Banjarmasin: FKIP Universitas Lambung Mangkurat, 2016. 
[6] Komite Nasional Pengelolaan Ekosistem Lahan Basah. Strategi Nasional dan Rencana Aksi Pengelolaan Lahan Basah Indonesia. Jakarta, 2004.

[7] A. Littlejohn, and C. Pegler, Preparing for blended e-learning. Routledge, 2007.
[8] I. M. Chirițescu, and F. A. Păunescu, Innovative Methods And Techniques Of Languages Teaching And Learning, International Journal of Arts \& Sciences, vol.10, pp. 375-382, 2017.

[9] K. Walsh, Blended learning. Bmj, vol. 330, pp. 829, 2005.

[10] A. Littlejohn, and C. Pegler, Preparing for blended e-learning. Routledge, 2007 